ISSN 2078-6441. Вісник Львівського університету. Серія географічна. 2013. Випуск 42. С. 196-203. Visnyk of the Lviv University. Series Geography. 2013. Issue 42. P. 196-203.

911.3:32

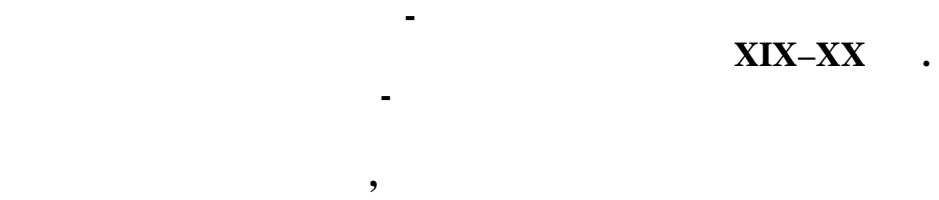

ьвівський н ціон льний університет імені в н вул. . орошенк , 41, 79000, м. ввів, кр їн

икон но ретроспективний н ліз дміністр тивно-територі льного устрою овківського р-ну. иявлено недоліки суч сного поділу, т кож вплив дміністр тивнотериторі льних змін н розселення н селення $\mathrm{p}$ йону. ведено рекоменд ції щодо вдоскон лення дміністр тивно-територі льного устрою овківщини н підст ві н лізу соці льно-демогр фічних н слідків минулих дміністр тивно-територі льних перетворень.

лючові слов : судовий повіт, фільв рок, гром д , волость, округ, р йон, міські, селищні т сільські р ди.

ит ння дміністр тивно-територі льних перетворень $€$ кту льним для кр їни впродовж усього періоду нез лежності, дже суч сн систем дміністр тивнотериторі льного упр вління в держ ві утворен без ур хув ння б г тьох об'єктивних демогр фічних, соці льно-економічних, етнокультурних особливостей, міжпоселенських зв'язків і є сп дком р дянського періоду. ході дміністр тивно-територі льної реформи передусім в жливо, щоб вон сприял розвитку поселень, з безпеченню комфортних умов життєдіяльності н селення. цьому контексті в рто вивчити досвід минулих схем дміністр тивно-територі льного устрою ( $)$, простежити їні нег тивні т позитивні н слідки впливу н соці льно-демогр фічні процеси. б г тьох схем х реформув ння , розроблених і вл дними структур ми, і н уковцями, особливу ув гу приділено реформув нню середньої т нижчої л нок, яким відповід ють дміністр тивні р йони і сільр ди, дже с ме н низовому рівні відчутніші н слідки минулих прор хунків територі льного упр вління.

б’єктом н шого дослідження є овківський р-н ьвівської обл., у якому протягом ост нніх двох століть відбув лись 6 г тор зові зміни поселенського скл ду, розмірів, ст тусу і н віть н зви. йон виділяється високою різном нітністю природних і соці льно-економічних умов, його можн розгляд ти як репрезент тивний полігон для розроблення методики суспільно-геогр фічного дослідження н лок льному рівні.

сторія формув ння овківського р-ну бере поч ток з 1867 р. - ч су утворення овківського повіту в меж х встро- горської імперії. цей період дміністр тивний повіт овківщини поділяли н три судові повіти, с ме: овкву, уликів, еликі

ости. гідно з переписом н селення від 31 грудня 1880 р., судовий повіт овкви охоплюв в 30 гром д т 15 фільв рків, у ньому прожив ло 28923 жителі. судовому повіті уликов н лічув лось 26 гром д, 20 фільв рків т 20917 осіб. о судового повіту еликих остів входило 18 гром д, 19 фільв рків, прожив ло 22024 мешк нці $[7$, с.9]. тже, овківський дміністр тивний повіт 3 г лом охоплюв в

(C) $о 3$ к ., клярськ ., 2013 
74 гром ди і 54 фільв рки із кількістю н селення 71864 особи, з яких 69591 особ н леж ли до гром д, 2273 - до фільв рків. ерев ж ли в повіті м лі гром ди. ише 21 гром д м л кількість н селення пон д 1 тисячу осіб.

н слідок нексії личини ольщею у 1920 р. н приєдн них укр їнських землях утворено три воєводств з центр ми у ьвові, ернополі й т нісл вові. ьвівське воєводство поділяли н 26 повітів, і територія суч сного овківського р-ну бул розподілен між чотирм повіт ми - овківським, в - уським, ородоцьким i ьвівським (рис. 1). гідно з дміністр тивним поділом від 1 квітня 1932 р., овківський повіт охоплюв в місто овкву, дв містечк н пр в х міст - уликів i еликі ости, т 68 сільських гром д. г льн площ повіту ст новил 1 110,97 км². цей період н території прожив ло 95206 осіб у 16925 будинк х.

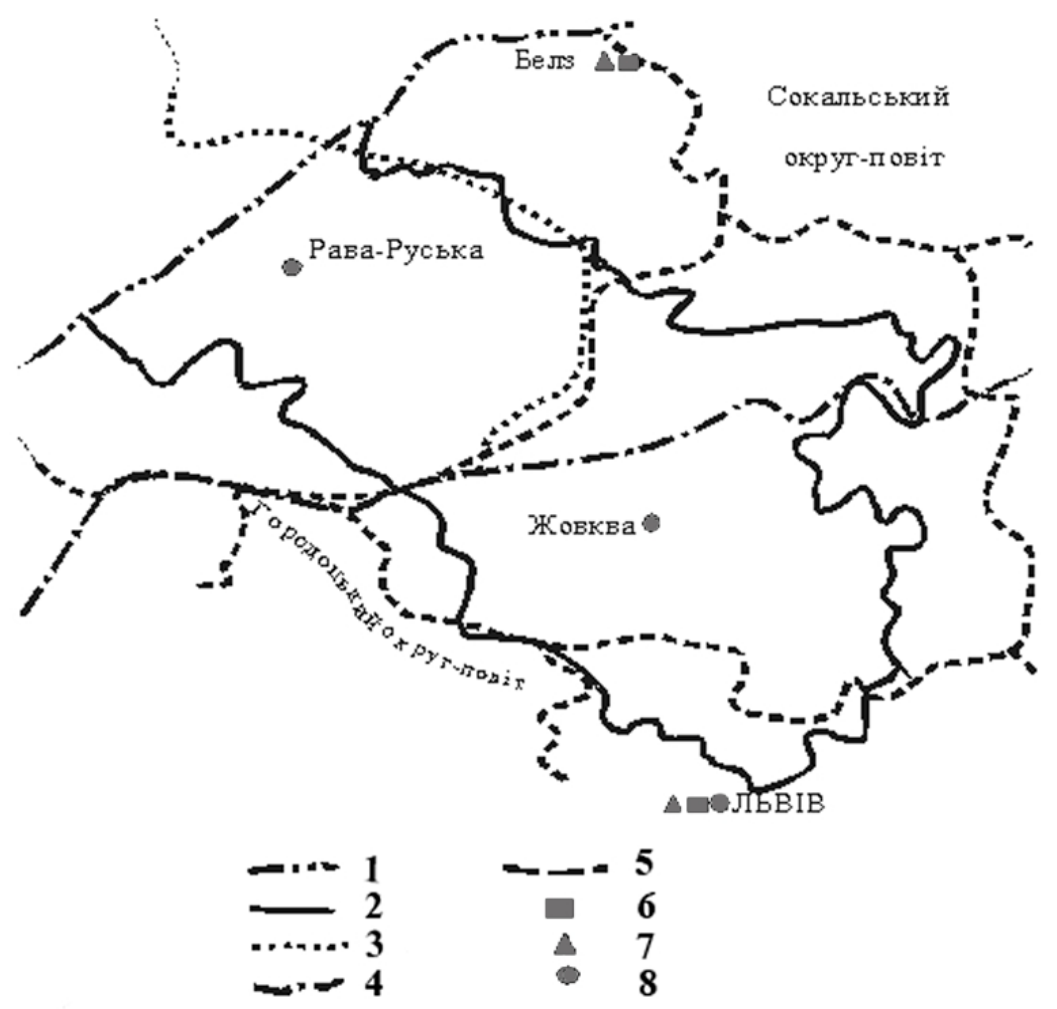

ис. 1. ормув ння території овківщини у XVIII-н поч тку ст.

1 - суч сний кордон; 2 - суч сні межі овківського р йону; 3 - межі повітів елзького воєводств ; 4 - гр ниці воєводств до 1772 р.; 5 - межі округів-повітів (1919-1939 рр.); 6 - центри воєводств (до 1772 р.); 7 - центри повітів і земель (до 1772 р.); 8 - центри округів-повітів. кл дено $з$ м тері л ми [2].

ерепис н селення 1931 р. свідчить про зрост ння кількості н селення в сільських поселеннях, ун слідок чого кількість гром д до 500 осіб зменшил ся з 28 до 18, 3 н селенням від 500 до 1000 осіб - з 25 до 17. ількість сіл, у яких прожив ло від 
1000 до 3000 осіб, зросл до 30. йбільшими сільськими поселеннями повіту н той ч с були овт нці (4 800 осіб), уринк (3 620) і унин (3 057 осіб). емогр фічні втр ти вн слідок воєн і емігр ції компенсув в порівняно високий природний приріст, т кож іммігр ція польського н селення [6].

серпні 1934 р. ольщ 3 пров дил в личині нову дміністр тивну одиницю збірну гром ду-волость. ільські гром ди овківського повіту було поділено між дев'ятьм гмін ми: утини, оля- исоцьк, іболки, олодно, рехів, окротин, еликі ости, дичі, уринк .

тнічний скл д н селення овківщини цього періоду достовірно відобр зив проф. . убійович у пр ці “ тнічні групи південно-з хідної кр їни ( личини)”, спир ючись н урядову ст тистику й церковні приписи. дослідженнями вченого, н 1 січня 1931 р. у овківському повіті прожив ли т кі етнічні спільноти: укр їнці (75 885 осіб), поляки $\quad(7455)$, л тинники $(8400), \quad$ євреї $(7420)$, німці й інші (1 590 осіб). г льн кількість н селення повіту ст новил 101970 осіб [4, с. 47-50]. к б чимо, укр їнці ст новили близько трьох четвертих від усього н селення овківщини. овкві з н селенням 11100 осіб, укр їнці (3 100 осіб) були н третьому місці після євреїв (4 270) і поляків (3 500). те укр їнське н селення утворюв ло н йбільшу етнічну спільноту еликих остів, бсолютно перев ж ло в уликові т в 61 сільській гром ді. одноч с н йбільші скупчення поляків були в овкві (3 500 осіб), еликих ост х (1 000), т нислівці (580), линську (365), опошині (310), еремивк х (285 осіб). кр їнськомовні римо-к толики (л тинники) жили більшими груп ми, то й поодинокими родин ми в 54 місцевостях овківщини, н йбільше - у олодному (1280 осіб), льничі (800), овт нцях (390), т рій кв ряві (350), олі- исоцькій (340) і лищивод х (330 осіб) [4, с. 64-66, 104-113].

ісля приєдн ння з хідноукр їнських земель до кр їнської більшовицькою вл дою впров джено прийнятний для р дянського періоду поділ н обл сті й р йони. території колишнього ьвівського воєводств в цей період утворено дві обл сті - ьвівську і рогобицьку. озміри й межі р йонів м йже відповід ли судовим повіт м встрійських ч сів. прикл д, н території овківського повіту існув ли три р йони: еликомостівський, овківський і уликівський (див. рис. 2). р йон х функціонув ли “міські р ди” для міст, “сільські р ди” для сіл і присілків. мінил сь і кількість сільських поселень р йонів, що головно було зумовлене розширенням мережі сільських поселень ун слідок проголошеного курсу н колективіз цію. окрем , протягом 1939-1940 рр. шляхом об'єдн ння ч стин геров з снов но село елике ередмістя, з декількох присілків м'янки- олоської - сел ліярники, оничі т ін. ідокремленням від великих сільських поселень їхніх присілків утворено т кі м лі сел овківського р йону, як итрейки, чм рі (р ніше н леж ли до с. унин), орнії (відокремлено від с. ев'ятир), т ре ело (від мянки- олоської), плітн (від с. лищиводи), леб ни, еликі олини (від с. отелич) т ін.

ч си німецької окуп ції личин н леж л до енер льної убернії, іiї передвоєнний дміністр тивний поділ було повернуто й повіти підпорядков но новоствореним округ м. ідт к територія суч сної овківщини в 1941-1944 рр. бул поділен між в - уським, овківським, м'янко- узьким і ьвівським округ ми.

ісля 1944 р., обл сний і р йонний поділ відновлено, у 1951 р. н зву овкв змінено н естеров, овківський р йон, відповідно, $-\mathrm{H}$ естеровський. 


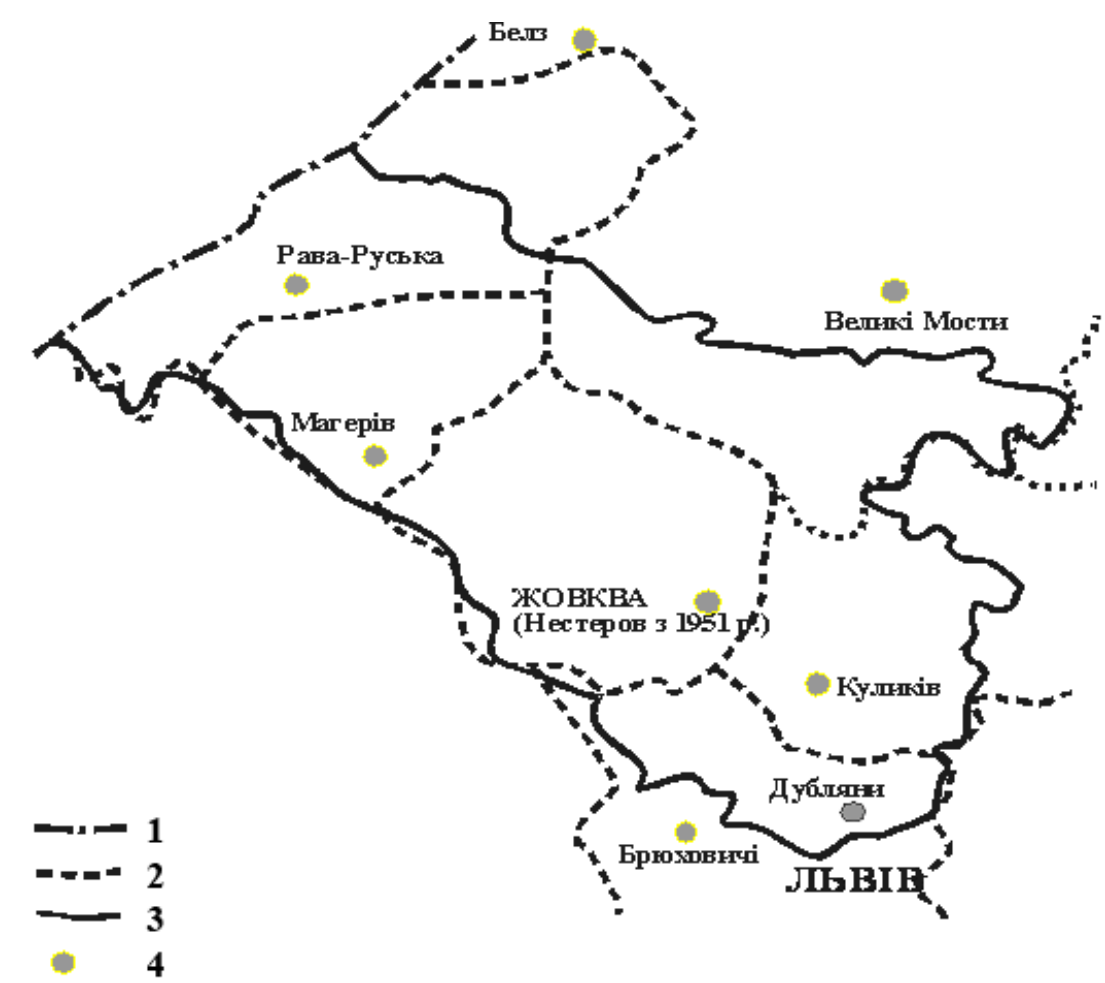

ис. 2. ормув ння території овківського р йону у другій половині ст.

1 - держ вний кордон; 2 - межі р йонів 1944-1962 pp.; 3 - суч сні межі р йону; 4 - центри р йонів. кл дено $з$ м тері л ми [2].

1959 р. ліквідов но уликівський р йон, його територію розподілено між инниківським, естеровським і овояричівським. ого ж року ліквідов но і еликомостівський $\mathrm{p}$ йон, його землі приєдн но до бузького, м'янко- узького т естеровського р йонів. іквід ція уликівського т еликомостівського $\mathrm{p}$ йонів збільшил естеровський р йон, водноч с від овківщини було відокремлено ч стину iii історично сформов них земель н користь м'янко- узького т ок льського p йонів.

змін ми дміністр тивно-територі льного поділу від 1 січня 1962 р., естеровський $\mathrm{p}$ йон охоплюв в естеровську міську, уликівську селищну т 16 сільських р д, центр ми яких були оянець, 'язов , еликі рибовичі, еревня, обросин, остиїв, рехів, юбеля, лехів, окротин, ове ело, ов кв ряв , ідлісне ( іболки), мереків, опошин і уринк [5, с. 44-49].

1964 р. територія естеровського р йону суттєво зросл вн слідок приєдн ння ліквідов ного в - уського р йону. тже, до естеревського р йону ввійшл в уськ міськ р д, герівськ селищн р д і вісім сільських р д: ишківськ, ійченськ, бірськ, мківськ, вриківськ, ипницьк, отелицьк т ічківськ .

зн чимо, що територі льне об'єдн ння двох дміністр тивних р йонів, колишніх польських повітів - в - уського т овківського, м ло суперечливі соці льно- 
демогр фічні н слідки. ередусім, т кі територі льні зміни призвели до втр ти ст тусу т функцій колишнього повітового, згодом р йонного центру - міст ви- уської. н слідок цього, зменшився і його демогр фічний потенці л: протягом 1931-1971 pр. кількість н селення ви- уської зменшил сь н 3600 осіб. осл бленню міжпоселенського зн чення міст посприяло т кож з кріплення винятково б р'єрних функцій p дянсько-польського кордону в повоєнний період, відт к усі поселення, розт шов ні в прикордонній смузі, ст ли периферійними і втр тили колишні комерційні міжпоселенські зв'язки з польськими поселеннями, зокрем 3 еремишлем. іншого боку, укрупнення овківського р йону н поч тку 1970-х років ктивізув ло зн чення,

т кож соці льно-демогр фічний і економічний потенці л овкви, дміністр тивний вплив якої поширився н пон д 180 н селених пунктів.

більшення демогр фічної в ги р йону т дміністр тивних функцій овкви ( естеров ) у повоєнний період відбулось і з вдяки приєдн нню до р йону ч стини території колишнього ьвівського повіту, с ме - ублянської міської р ди ( убляни, лехів, лі ідліски, итихів), рибовицької ( еликі т лі рибовичі, оля- омулецьк, ряд , бир нк ) і шківської ( шків, в дів, рудці) сільських р д т сел остиїв уликівської селищної р ди. тже, вн слідок цих дміністр тивно-територі льних змін р йон безпосередньо межує з обл сним центром, що поповнює перелік позитивних рис його суспільно-геогр фічного положення. опри це, місто убляни, сел лехів і еликі рибовичі розміщені в зоні потужного впливу ьвов , відт к м ють дуже сл бкі міжпоселенські зв'язки з р йонним центром.

гідно 3 дміністр тивним поділом від 1 січня 1972 р., естеровський р йон охоплюв в тоді дві міські р ди - естеровську т в - уську, три селищні ди ублянську, уликівську, герівську, т 25 сільських р д. ктично, в цей ч с р йон сягнув своїх теперішніх меж [8, с. 12-13].

оселенський скл д р йону теж ч сто змінюв вся у р дянський період. окрем з зн в ли змін кількість н селених пунктів і сільських р д, т кож н зви поселень, якот овкв - естеров, уд - існ - вриків, окротин- ідродження, іболкиідлісне, ільки- зовецькі- олиця, т - ідгородне т ін. ротягом 1972-1979 pр. ліквідов но 'язівську, ев'ятирську т мереківську сільські р ди, що призвело до втр ти дміністр тивних функцій однойменних сіл, згодом до їхнього соці льноекономічного з неп ду і демогр фічного скорочення. собливо помітними виявились нег тивні н слідки р дянських дміністр тивних змін для сел ев’ятир, яке було одним з н йбільш розвинутих сіл кр ю і з переписом 1921 р. н лічув ло 2012 жителів, нині в цьому селі прожив є тільки 196 осіб.

зом із міськими т селищними р д ми н прикінці 70-х років ст. естеровський р йон охоплюв в 196 н селених пунктів [6, 7, с. 10-19]. ого площ ст новил 1 294,4 км² , н н 183,43 км² більше від площі передвоєнної овківщини.

о поч тку 1990-х років межі й площ р йону не змінюв лись, одн к кількість сільр д збільшил ся н 15 одиниць. 1991 p. естеровський р йон знову ст в овківським. прикінці -н поч тку ст. до скл ду р йону ввійшло три міські, дві селищні т 40 сільських р д. г льн кількість поселень - 165, що н 31 поселення менше, ніж н поч тку 1990-х років. меншення кількості поселень відбулось головно вн слідок об'єдн ння м лих сіл; тільки п'ять сільських поселень були зняті з обліку з цей період.

ьогодні територія овківського р йону охоплює ч стини різних у минулому дміністр тивно-територі льних одиниць т простяг ється 3 північного 3 ходу н 
південний схід н пон д 60 км. озитивними н слідк ми розглянутих вище історичних тенденцій територільного розвитку є суч сне прикордонне положення $\mathrm{p}$ йону, т кож його безпосередне межув ння 3 обл сним центром. дн к б г тор зові дміністр тивно-територі льні зміни т низьк комп ктність суч сної території р йону не сприяли формув нню стійкої р йонної системи розселення. ередусім дест білізують р йонну розселенську систему поселення, прилеглі до ьвов . х обслуговув льним і притяг льним ядром є місто ьвів, відт к 3 р йонним центром ці поселення пов'яз ні тільки дміністр тивно. к ситу ція цілком очевидн $з$ огляду н близькість до обл сного центру (зокрем , відст нь від ублян до ьвов - тільки 6 км), т кож довготрив лу н лежність прильвівських поселень р йону до ьвівського округу, згодом - однойменного повіту. ро сл бкий зв'язок ублян і прилеглих сіл 3 овквою свідчить конфігур ція тр нспортної мережі: з лізничні гілки зі ьвов через убляни проходять тільки в н прямі ок ля, переїзд з цих поселень р йону до овкви м ршрутними втобус ми можливий лише з перес дкою у ьвові. осі не ре лізов но проекту прямого сполучення ублян з р йцентром, попри те, що б г то жителів міст пр цюють н підприємств х овкви.

роблемні моменти є і в комунік ції поселень прикордонної смуги з овквою т оптим льному обслуговув нні їхніх жителів у р йцентрі. ідст нь від прикордонних поселень до овкви ст новить 30-40 км, до ьвов - 50-60 км, відт к обслуговув ння 3 кл д ми й уст нов ми р йонного центру жителі ч сто розгляд ють 3 тією ж мірою доступності, як можлив і в обл сному центрі. ег тивні соці льно-демогр фічні й економічні явищ, які виник ють ун слідок сл бких міжпоселенських зв'язків,

т кож н явність міського поселення зі зн чним р діусом демогр фічного впливу у прикордонній зоні грументують утворення ( бо відновлення) в - уського р йону.

е н йбільш оптим льний спосіб вирішення суч сних дміністр тивно-територі льних проблем з ур хув ннях об'єктивних суспільно-геогр фічних передумов, с ме н явності міцної т великої з розмір ми кущової системи розселення, що сформув л сь н вколо ви- уської, т специфіки способу життя н селення прикордонної смуги.

тже, неоднор зові зміни ст тусу, скл ду т розмірів овківського $\mathrm{p}$ йону впродовж кінця - ст. м ють низку нег тивних суспільно-геогр фічних н слідків, подол ння яких потребує конструктивних дміністр тивно-територі льних перетворень. оловними з вд ннями цих змін м $є$ бути посилення зв'язків лок льних територі льних гром д 3 р йонним центром, зрост ння функцій і ст тусу міських поселень т соці льно-економічний розвиток сіл. осягнення т ких позитивних результ тів можливе не вн слідок докорінного дміністр тивно-територі льного реформув ння, що пропонують окремі політики (н прикл д, укрупнення лок льних територі льних гром д т дміністр тивних р йонів 3 реформою . езсмерного т схожі проекти нинішнього уряду), 3 вдяки помірков ним і поступовим змін м відповідно до сформов них регіон льних особливостей розселення. 
1. ністрянський . . олітичн геогр фія т геополітик . . ністрянський. - ернопіль : огд н, 2010. - 344 с.

2. овківщин . сторичний н рис / [3 ред. . итвин ]. - овкв ; ьвів; лтимор : н-т укр їнозн вств ім. . рип'якевич кр їни, емляцьке об'єдн ння “ овківщин ", 1994. - . 1.-326 с.

3. рип'якевич. історії овкви / . рип'якевич // писки ин св. силія еликого. - ьвів, 1935. - .6, ип. 1-2. - .40-69.

4. убійович . тнічні групи пд.-зх. кр їни ( личини) н 1.1 .1939 р.: ціон льн ст тистик личини. - ісб ден, 1983. (перевид. з доповн.) ьвів: ид вничий ім “ $\quad$ ", 2007. - 173 с.

5. ьвівськ обл сть. дміністр тивно-територі льний поділ. . 1 / . лейніков. ьвів : “ кр їнські технології, 2005. - . 44-49.

6. ливк . естеровський р йон. естеров / . ливк // сторія міст і сіл : ьвівськ обл. - ., 1968. - .498-510.

7. есюк . овківщин : історія, культур, туризм / . есюк. - ьвів : лицьк вид внич спілк , 2007. - 79 с.

8. Charchut A. Odkryj swój szlak...: powiat kraśnicki - rejon ółkiewski : polskoukraińsko-angielska wersja językowa: [praca zbiorowa] / Anita Charchut, Ewa Kamińska, Leszek Mościcki. - Krasnik : Wydawnictwo MAD Graf, 2004. - 141 s.

m ття: н дійшл до ред кції 29.04.2013

доопр иьов н 05.07 .2013

прийнят до друку 10.10.2013

\section{ADMINISTRATIVE AND TERRITORIAL CHANGES OF PUBLIC WELFARE OF ZHOVKVA DISTRICT AND ITS SOCIAL AND GEOGRAPHICAL CONSEQUENCES DURING XIX-XX CENT.}

\section{Taras Kozak, Oksana Sklyarska}

Ivan Franko National University of Lviv, P. Doroshenko Str., 41, UA - 79000 Lviv, Ukraine

Historical analysis of administrative and territorial public welfare was fulfilled on the territory of Zhovkva district. The drawbacks of division have been defined and the interdependence between the administrative and territorial changes and population of district settlements has been established. The recommendations concerning the improvement of administrative and territorial public welfare in Zhovkva district have been defined on the basis of studying the influence of administrative and territorial changes on the social-demographic conseguences.

Key words: judicial district, country seat, community, parish, county, district, city, town and village councils. 


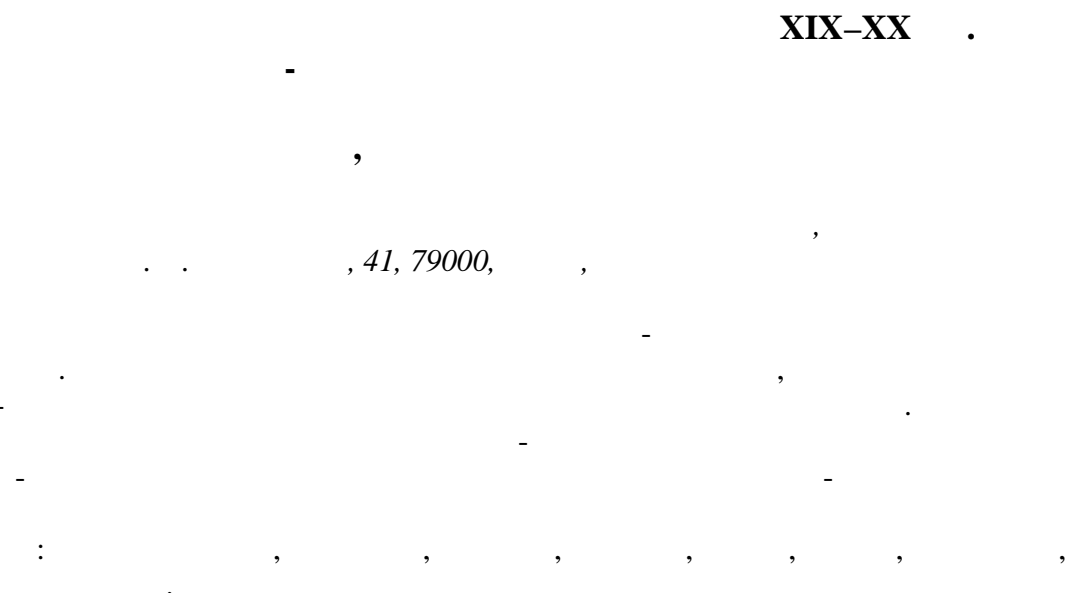

существлено ретроспективный н лиз дминистр тивно-территори льного устройств олковского $\mathrm{p}$ йон . боснов но недост тки современного деления, т кже влияние дминистр тивно-территори льных изменений н $\mathrm{p}$ сселение н селения $\mathrm{p}$ йон . тмечено рекоменд ции по совершенствов нию дминистр тивно-территори льного устройств н основе н лиз соци льно-демогр фических последствий прошлых дминистр тивно-территори льных преобр зов ний.

лючевые слов : судебный уезд, поместье, общин, волость, округ, р йон, городские, поселковые и сельские советы. 